\title{
Moonlighting proteins are variably exposed at the cell surfaces of Candida glabrata, Candida parapsilosis and Candida tropicalis under certain growth conditions
}

\author{
Justyna Karkowska-Kuleta ${ }^{1 *}$, Dorota Satala², Oliwia Bochenska², Maria Rapala-Kozik and Andrzej Kozik²
}

\begin{abstract}
Background: Adaptability to different environmental conditions is an essential characteristic of pathogenic microorganisms as it facilitates their invasion of host organisms. The most external component of pathogenic yeast-like fungi from the Candida genus is the multilayered cell wall. This structure is composed mainly of complex polysaccharides and proteins that can undergo dynamic changes to adapt to the environmental conditions of colonized niches.

Results: We utilized cell surface shaving with trypsin and a shotgun proteomic approach to reveal the surfaceexposed proteins of three important non-albicans Candida species-C. glabrata, C. parapsilosis and C. tropicalis. These proteinaceous components were identified after the growth of the fungal cells in various culture media, including artificial saliva, artificial urine and vagina-simulative medium under aerobic conditions and anaerobically in rich YPD medium. Several known proteins involved in cell wall maintenance and fungal pathogenesis were identified at the cell surface as were a number of atypical cell wall components—-pyruvate decarboxylase (Pdc11), enolase (Eno1) and glyceraldehyde-3phosphate dehydrogenase (Tdh3) which are so-called 'moonlighting' proteins. Notably, many of these proteins showed significant upregulation at the cell surface in growth media mimicking the conditions of infection compared to defined synthetic medium.

Conclusions: Moonlighting proteins are expressed under diverse conditions at the cell walls of the C. glabrata, C. parapsilosis and C. tropicalis fungal pathogens. This indicates a possible universal surface-associated role of these factors in the physiology of these fungi and in the pathology of the infections they cause.
\end{abstract}

Keywords: Non-albicans Candida species, Candidiasis, Cell wall, Enolase, Cell surface proteome

\section{Background}

Pathogenic microorganisms possess the important ability to adapt readily to different environmental conditions, which they exploit when colonizing new infectious niches in a host organism. During the initiation and development of the infectious process, these microbes typically have to contend with changes in temperature, $\mathrm{pH}$, and osmolarity, the variable availability of oxygen and nutrients, oxidative stress and the host immune

\footnotetext{
* Correspondence: justyna.karkowska@uj.edu.pl

${ }^{1}$ Department of Comparative Biochemistry and Bioanalytics, Faculty of Biochemistry, Biophysics and Biotechnology, Jagiellonian University, Gronostajowa 7, 30-387, Krakow, Poland

Full list of author information is available at the end of the article
}

response. This may require not only the use of an entire suite of classic virulence factors, such as hydrolytic enzymes, toxins or adhesins, but also other less obvious or not well-known mechanisms that enable microbial survival in the face of adverse environmental conditions. One such unusual mechanism may be cell surface enzymes that originate in the cytoplasm in the pathogens and are primarily involved in essential intracellular metabolic processes such as glycolysis, the citric acid cycle or the pentose phosphate pathway [1]. A cellular location that is completely different from the original suggests an alternate function for such factors that is not caused by gene fusions or splicing variations. The term

(c) The Author(s). 2019 Open Access This article is distributed under the terms of the Creative Commons Attribution 4.0 International License (http://creativecommons.org/licenses/by/4.0/), which permits unrestricted use, distribution, and 
"moonlighting proteins" was coined as a result [2]. The functional strategy involved in this instance is successfully used by many species of pathogenic bacteria in which surface-exposed moonlighting proteins play an important role in the process of adhesion to host cells and tissues, binding of numerous proteinaceous targets within the host organism, and evasion of the immune system $[3,4]$.

This phenomenon has also been described for yeast-like fungi from the Candida genus. These microbes have the potential to be dangerous pathogens in humans that can cause not only frequently occurring superficial infections of the skin and mucosal surfaces, but also invasive, systemic infections, especially in a host with impaired immunity $[5,6]$. Several moonlighting proteins exposed on the cell surface of C. albicans, C. tropicalis and C. parapsilosis have been identified as binding partners for human extracellular matrix proteins $[7,8]$, plasminogen and components of the complement system and kinin-generating system [9-14], and even as molecules that mediate the binding of fungal cells to human cells [15]. Moreover, moonlighting proteins from different Candida species can play a role in the adhesion of fungi to medical devices made of silicone or polyvinyl chloride [16].

A potential protective role of surface-exposed moonlighting proteins has recently been proposed as a response to oxidative stress caused by $\mathrm{H}_{2} \mathrm{O}_{2}$ in $C$. albicans, C. glabrata, C. krusei and C. parapsilosis. It was demonstrated that several metabolic enzymes present at the cell wall of these fungi grown in liquid media or in sessile cells forming biofilms might represent a primary line of fungal defense against reactive oxygen species generated during phagocytic respiratory burst in conjunction with typical antioxidant systems $[17,18]$. This particular mechanism, in tandem with the ability to adhere to different biotic and abiotic surfaces and to influence the action of important plasma proteolytic cascades, can significantly contribute to the virulence of Candida fungi. The invasion of the host organism and colonization of new niches by fungal cells undoubtedly require a dynamic adaptation of these microorganisms to new environmental conditions, including changes to their cell wall proteome [19]. However, given that significant changes in the frequency of infections caused by particular Candida species have been observed and that species other than C. albicans, mainly C. glabrata, C. parapsilosis and C. tropicalis, have been indicated as the cause of superficial and invasive candidiasis [20-22], particular attention should be paid to the pathogenicity-related attributes of these other species, as they are increasingly reported to be a major threat for individuals with impaired immunity. For $C$. albicans, the cell wall structure and changes in its proteome is relatively well characterized but there have been less reports on the composition of the cell walls of other species of Candida genus. Among the proteins present at the surface of C. albicans cells, many moonlighting proteins have been repeatedly described, including enolase (Eno1), glyceraldehyde-3-phosphate dehydrogenase (Tdh3), alcohol dehydrogenase (Adh1), phosphoglycerate kinase (Pgk1), transaldolase (Tal1), pyruvate decarboxylase (Pdc11) and others [23-25]. As significant differences in virulence attributes between species can be expected, including a variability of protein exposition at the cell surface, this may result in discrepancies in pathogenhost interactions, the increase of incidence of candidiases caused by species other than the well described $C$. albicans and greater difficulties in the treatment of such infections. Hence, the aim of our current study was to investigate overall changes in the surface exposure of cell wall-associated proteins in C. glabrata, C. parapsilosis and $C$. tropicalis. We did these analyses under growth conditions mimicking the microenvironment at different body sites that could potentially be colonized by these pathogens, with a particular emphasis on the contribution of moonlighting proteins to the entire repertoire exposed on the candidal cell surface.

\section{Results}

Diverse proteins present on the cell surfaces of $C$. glabrata, C. parapsilosis and C. tropicalis depending on the growth conditions

The detection and quantification of the proteins expressed on the C. glabrata, C. parapsilosis or C. tropicalis cell surface involved the tryptic digestion of these factors without disturbing the integrity of the cells followed by peptide separation and identification via LCMS/MS (high performance liquid chromatographycoupled tandem mass spectrometry) [26].

We analyzed three biological replicates and only further evaluated the proteins that were detected at least twice. In total, 53 proteins for C. glabrata, 37 for C. parapsilosis and 13 for $C$. tropicalis were identified at the fungal cell surface under all of the tested growth conditions. Notably however, a significant degree of quantitative and qualitative diversity was evident depending on the culture media used (Additional file 1: Table S1, Additional file 2: Table S2, Additional file 3: Table S3 and Additional file 4: Table S4). The highest number of proteins was detected for each species when using YPD medium under anaerobic conditions (AN) (29, 27 and 11 for C. glabrata, C. parapsilosis and C. tropicalis, respectively). The lowest number of $C$. glabrata proteins (8) and C. parapsilosis proteins (6) was detected after growth in vagina-simulative medium (VS), and for $C$. tropicalis following cultivation in artificial urine (AU) (1).

The use of different culture conditions, principally the composition of the medium, a $\mathrm{pH}$ range from 4.2 to 7.0, and a variation in oxygen availability (normoxia vs. 
anoxia), allowed the identification of several groups of proteins exposed at the surface of C. glabrata, C. parapsilosis and C. tropicalis cells. These functionally diverse groups were distinguished by their gene ontology (GO) annotations with regard to the particular molecular and biological processes in which they were involved. Appropriate GO annotations for each of C. glabrata, C. parapsilosis or C. tropicalis orthologous genes were assigned based on the information from the Candida Genome Database (CGD, http://www.candidagenome.org) [27] or Saccharomyces Genome Database (SGD, https://www. yeastgenome.org) [28]. Five major groups of proteins were thereby specified, including (i) typical cell wall proteins and secreted proteins equipped with a signal peptide, and involved in cell wall maintenance and fungal pathogenesis, (ii) stress response proteins, (iii) atypical cell wall proteins, i.e. moonlighting proteins, (iv) ribosomal and nuclear proteins, and (v) proteins of unknown function. Under the culture conditions used in our experiments, we observed a large variation between individual groups of proteins detected after growth in specific media, and found that not all groups were represented when different media were used (Fig. 1).

The lowest level of functional variability in C. glabrata and $C$. parapsilosis was observed after growth in vaginasimulative medium. Only typical cell wall proteins and secreted proteins were identified for these species under these conditions with some additional moonlighting proteins for C. glabrata, together with a few proteins of unknown function in both species. For $C$. tropicalis, the functional diversity of the identified proteins was generally reduced compared to the other two non-albicans Candida species. This was consistent with our observation of a generally smaller number of surface proteins detected for $C$. tropicalis under our current experimental culture conditions. Indeed, only one surface-exposed moonlighting protein was detectable in C. tropicalis using our method after growth in artificial urine. Moonlighting proteins were detected at the surfaces of almost all of our tested species grown in almost every culture medium used in our present analysis, and then accounted for at least $25 \%$ of a total protein pool. The one exception was $C$. parapsilosis cultivated in vaginasimulative medium. A more detailed qualitative comparison of the similarities and differences between the complete sets of cell surface proteins in the three investigated Candida species was conducted to determine the number of orthologous proteins shared between them (Fig. 2). When only moonlighting proteins and all other surface-exposed proteins were analyzed, three atypical cell wall proteins (Pdc11, Eno1 and Tdh3) were found to be shared by all three tested species and eight by $C$. parapsilosis and C. glabrata. Moreover, three and eight moonlighting proteins were identified to be exclusive to the first and latter species, respectively. Analogous analysis of the second separate group containing all other cell wall proteins showed in contrast to the first group that only one orthologous protein was shared by all three investigated species (the cell wall mannoprotein Mp65). Three orthologous proteins were shared by $C$. glabrata and C. parapsilosis (heat shock protein Ssa2, heat shock protein Hsp12, elongation factor 2) and two by the latter species and C. tropicalis (yeast-form wall protein Ywp1 and inducible acid phosphatase Pho100). In addition, more proteins from this second group were indicated to be unique to individual species, i.e., 7 for $C$. tropicalis, 18 for C. parapsilosis and 30 for C. glabrata.

\section{Expression changes in moonlighting proteins at the cell surfaces of C. glabrata, C. parapsilosis and C. tropicalis} Considering a potentially important function of moonlighting proteins in fungal pathogenesis and adhesion, an unusual route of their secretion and interspecies differences and similarities in their distribution, further attention was focused only on this particular group of surface-exposed proteins. On the basis of GO annotations concerning the molecular functions and biological processes assigned to cell wall proteins, expression changes in moonlighting proteins at the surface of $C$. glabrata, C. parapsilosis or C. tropicalis cells were quantitatively analyzed. Four types of culture media of a different composition and $\mathrm{pH}$ were employed as they simulate different potential sites of infection such as the oral cavity (artificial saliva, AS, pH 7.0) [29], vaginal microenvironment (vagina-simulative medium, VS, $\mathrm{pH}$ 4.2) [30], the urinary tract (artificial urine, $\mathrm{AU}, \mathrm{pH} 5.8$ ) [31] and gastrointestinal tract (YPD medium under anaerobic conditions) [32-34]. A synthetic medium (DS) with a particular amino acid composition [35] was used as a reference to compare the protein groups present at the fungal cell wall under the different culture conditions. In the analysis, normalized spectral abundance factors (NSAFs), that quantitatively indicate the level of each moonlighting protein at the cell surface in different media, were calculated and analyzed in terms of statistically significant differences (Tables 1,2 and 3 ). In $C$. glabrata, eight moonlighting proteins were detected after growth both in DS and in at least one other medium, and a significant increase in the amount of five proteins at the cell surface was also observed in relation to DS conditions. Moreover, 11 additional moonlighting proteins were detected in C. glabrata alone after growth in AS, VS, AU or anaerobic conditions, but not in the synthetic medium. In C. parapsilosis, only four moonlighting proteins were detected in DS cultures, and an additional 10 proteins were identified in this microbe after growth in AS, AU or AN. No moonlighting proteins were found at the $C$. parapsilosis cell surface after 


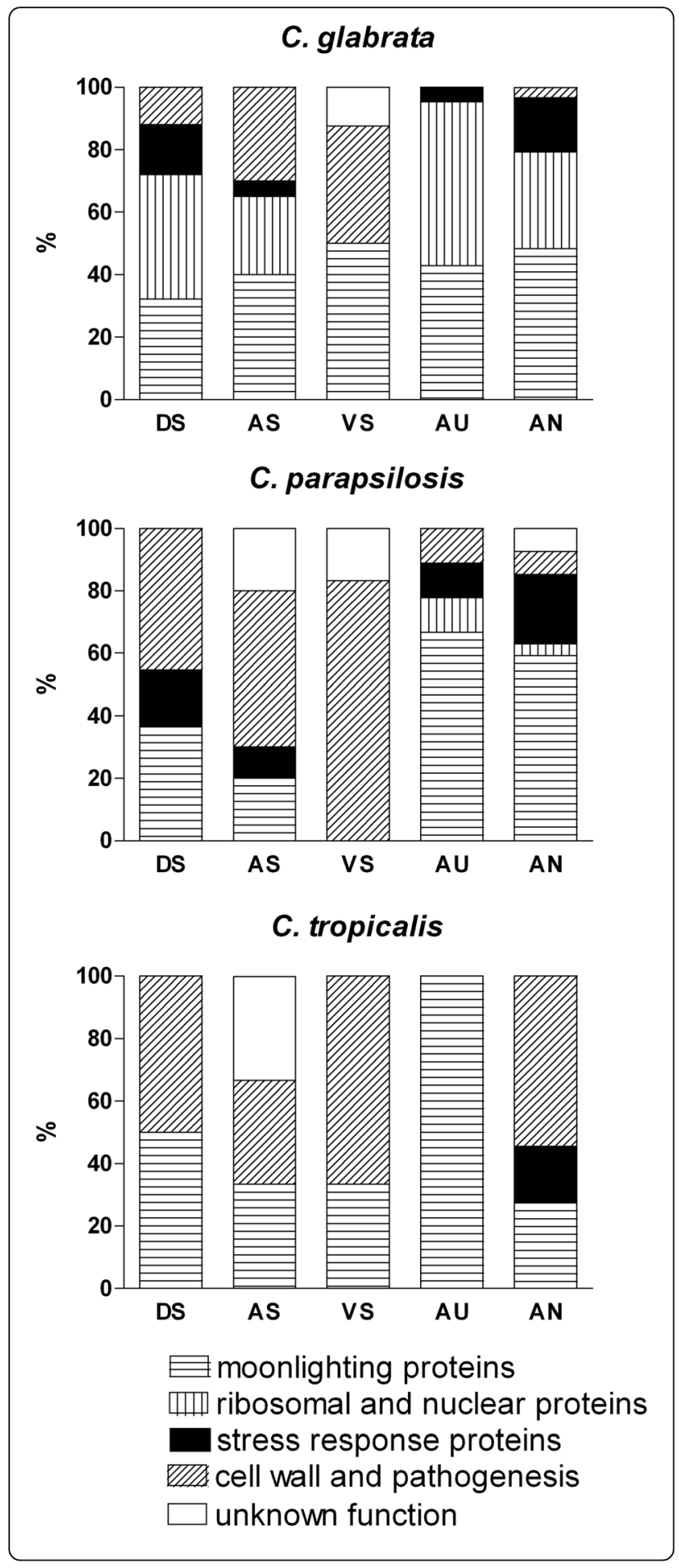

Fig. 1 Distribution of surface-exposed fungal proteins and their division into major functional groups. C. glabrata, C. parapsilosis and C. tropicalis cells were cultured aerobically in different growth media at $37^{\circ} \mathrm{C}$ for $16 \mathrm{~h}$ (DS, an amino acid-based, chemically defined liquid synthetic medium; AS, artificial saliva, VS, vagina-simulative medium, and AU, artificial urine) or cultured for $72 \mathrm{~h}$ in YPD medium under anaerobic conditions (AN). Surface-exposed proteins were identified by cell surface shaving with trypsin followed by liquid chromatography coupled to tandem mass spectrometry. The protein classifications were made on the basis of the Gene Ontology (GO) annotations (molecular function and involvement in similar cellular processes) from the Candida Genome Database (CGD) and Saccharomyces Genome Database (SGD)

growth in VS medium. Moreover, only three moonlighting factors were detected at the surface of $C$. tropicalis cells (Pdc11, Eno1 and Tdh3) when this fungus was grown in DS medium and in AN. Notably also, an increased abundance of individual moonlighting proteins at the cell surface was observed mainly after growth in other media under aerobic conditions (Eno1 in AS and Tdh3 in VS), but not under anaerobic conditions. Relative differences in the level of expression of selected surface-exposed moonlighting proteins are shown in Additional file 5: Figure S1.

\section{Discussion}

The cell wall of fungi from the Candida genus is not a rigid, static structure, but it is an important external organelle of the cell that is subjected to dynamic changes in response to various environmental conditions. Composed mainly of $\mathrm{N}$ - and O-mannosylated proteins, other proteins, $\beta-1,3-$ and $\beta-1,6$-glucans, chitin and small amounts of lipids, the cell wall is a part of the pathogenic fungal microbe that has an immediate and constant contact with the host during infection. Hence, it can play not only a protective role against host immune defenses and environmental stress stimuli, but also an active part in the pathogenesis of infections via cell surface virulence factors [36]. Although the general cell wall structure is similar among the species within the genus Candida, there are differences in this composition between different species and strains, or even different morphological forms of fungi $[37,38]$. In our previous study, we reported differences between the sets of proteins exposed at the surface of C. parapsilosis and C. tropicalis cells grown in YPD or RPMI 1640 culture media that affected the fungal morphology and were indicative of a large diversity among these factors [26].

There are several distinct groups among the known candidal cell wall proteins. Covalently bound fungal cell wall proteins are highly glycosylated, equipped with a motif that facilitates a classical secretion process and are linked to cell wall polysaccharides or other cell wall proteins via a glycosylphosphatidylinositol (GPI) anchor, alkali-sensitive linkages or disulfide bridges. However, a 


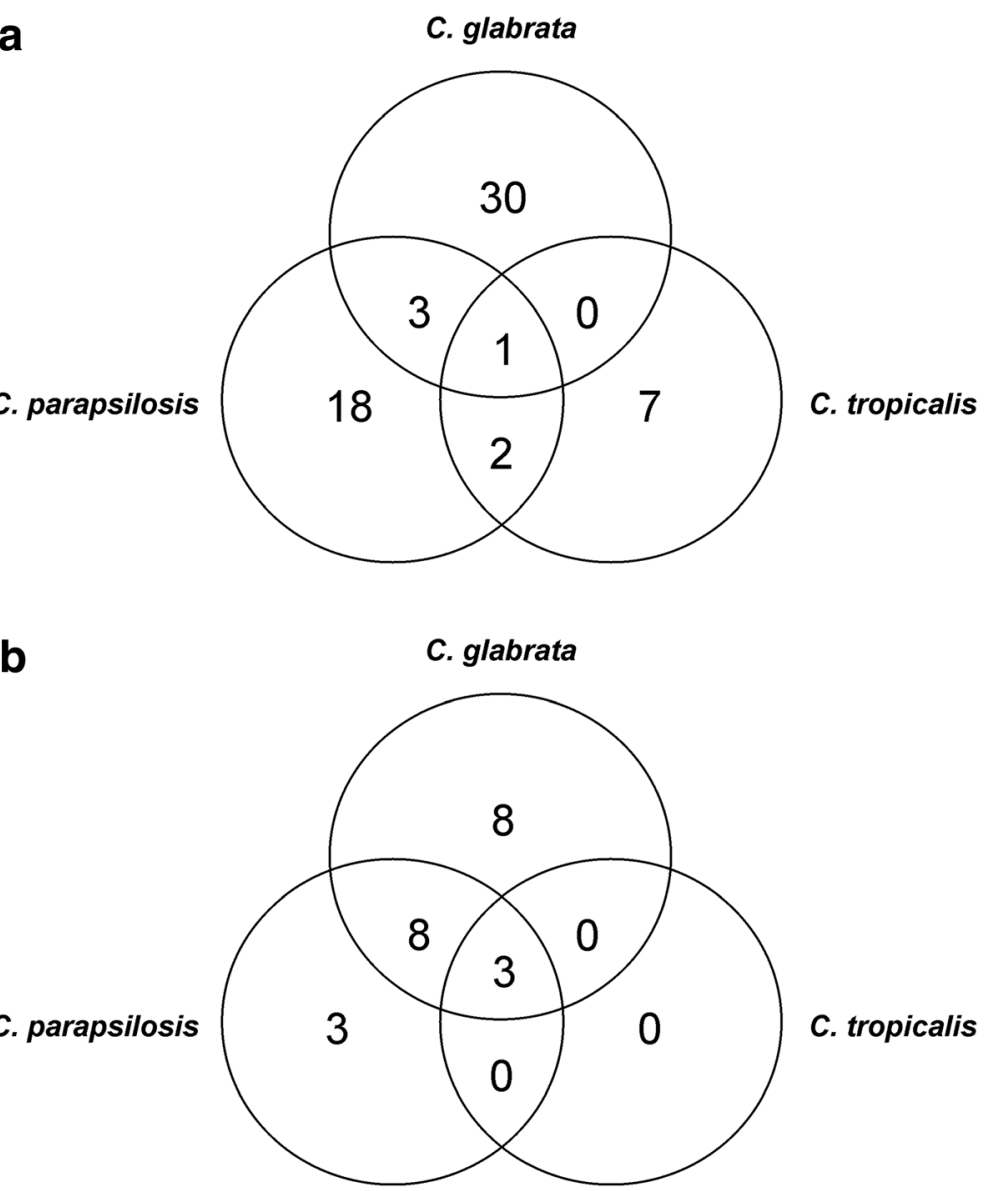

Fig. 2 Venn diagrams indicating the number of surface-exposed orthologous proteins shared between Candida species. C. glabrata, C. parapsilosis and C. tropicalis cells were cultured for 16 or $72 \mathrm{~h}$ at $37^{\circ} \mathrm{C}$ and then cell surface shaved with trypsin to identify surface-exposed proteins via LC-MS/MS. The functions of the identified proteins were assigned on the basis of GO annotations from the CGD and SGD. The numbers of shared or exclusive orthologous proteins identified in C. glabrata, C. parapsilosis and C. tropicalis were compared according to the two major groups of proteins identified under all tested growth conditions i.e. $\mathbf{a}$, typical cell wall proteins, stress response proteins, ribosomal and nuclear proteins and proteins with unknown function; and $\mathbf{b}$, moonlighting proteins, that are metabolic enzymes primarily involved in essential intracellular metabolic processes

number of atypical proteins of cytoplasmic origin are also present at the surface of Candida cells [39, 40]. These proteins of an undefined way of secretion, that play a completely different role at the cell surface than in the cytoplasm are known as moonlighting proteins and are increasingly considered to be important factors in fungal virulence [41]. One hypothesis is that these evolutionary conserved proteins become exposed at the cell wall of a fungal pathogen and function in molecular mimicry pathways. This possibility is due to the high similarity of these factors with host proteins which will help the invading microbes to thwart the host's immune system [42].

With the use of a cell surface shaving method with trypsin in combination with a shotgun proteomic approach, we have here identified cell surface proteins from three species from the Candida genus-C. glabrata, C. parapsilosis and C. tropicalis. These fungi were grown in four different culture media that resemble to some extent the conditions prevailing in niches of potential infection. These include the oral cavity, vagina, and the gastrointestinal and urinary tracts. These sites vary in terms of the availability of oxygen, $\mathrm{pH}$ (acidic in the vagina and urine, close to neutral in saliva) and various sources of carbon and nitrogen. For C. albicans, significant changes in the proteome have often been described for different culture conditions. Previous studies have reported that growth under hypoxic conditions in vagina-simulative medium with iron restriction induces the expression of $C$. albicans typical cell wall proteins Als3, Hwp1, Sim1, Tos1, Utr2, Pir1, Pga10 and Rbt5 [43, 44]. In addition, the $\mathrm{pH}$ has a known impact on the cell wall proteome of $C$. albicans; the abundance of different proteins is reported to increase at $\mathrm{pH} 7.0$ (i.e., Als1, Als3, Hyr1, Sod5 and others) compared to pH 4.0 (Phr2, Als4) [45]. Growth media containing different carbon sources (glucose vs. lactate) mediates the 


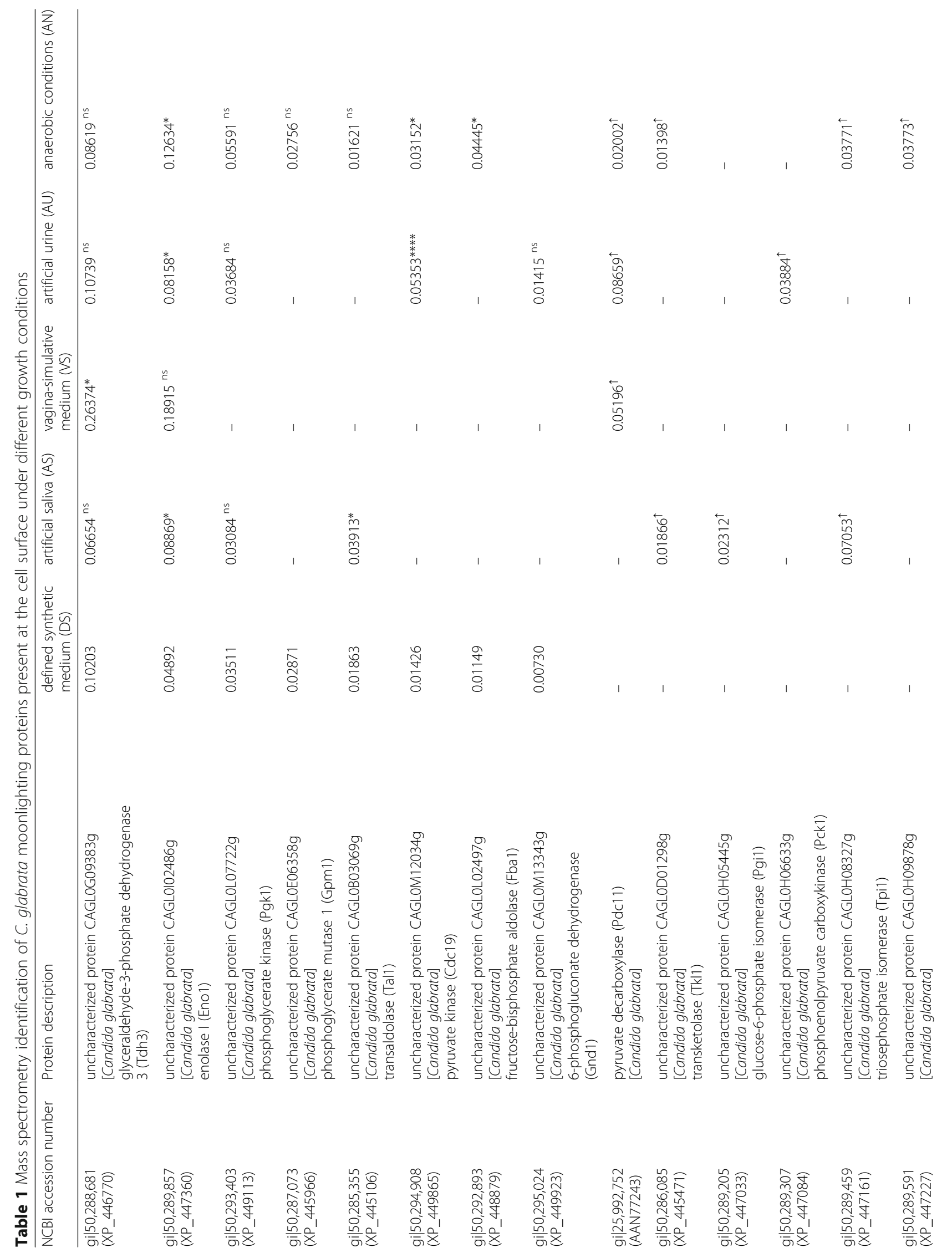




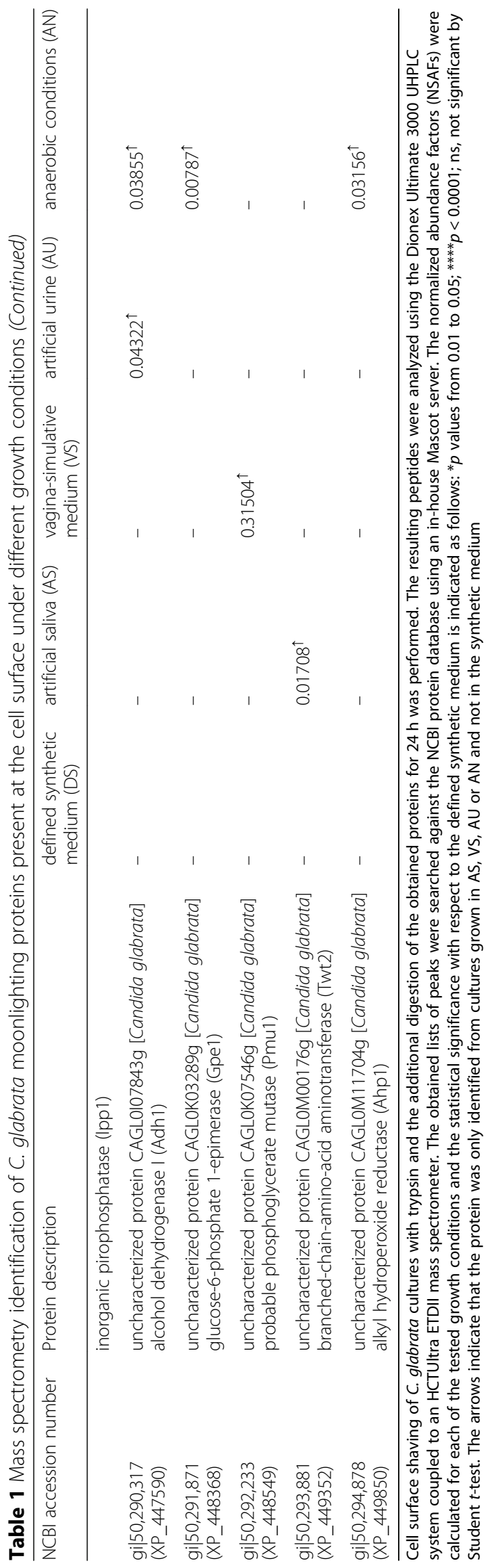


Table 2 Mass spectrometry identification of C. parapsilosis moonlighting proteins present at the cell surface under different growth conditions

\begin{tabular}{|c|c|c|c|c|c|c|}
\hline $\begin{array}{l}\text { NCBI accession } \\
\text { number }\end{array}$ & Protein description & $\begin{array}{l}\text { defined synthetic } \\
\text { medium (DS) }\end{array}$ & $\begin{array}{l}\text { artificial } \\
\text { saliva (AS) }\end{array}$ & $\begin{array}{l}\text { vagina-simulative } \\
\text { medium (VS) }\end{array}$ & $\begin{array}{l}\text { artificial } \\
\text { urine }(A U)\end{array}$ & $\begin{array}{l}\text { anaerobic } \\
\text { conditions (AN) }\end{array}$ \\
\hline $\begin{array}{l}\text { gi|354,546,348 } \\
\text { (CCE43078) }\end{array}$ & $\begin{array}{l}\text { hypothetical protein CPAR2_207210 } \\
\text { [Candida parapsilosis] } \\
\text { enolase (Eno1) }\end{array}$ & 0.07214 & - & - & $0.09507^{\mathrm{ns}}$ & $0.06579^{\mathrm{ns}}$ \\
\hline $\begin{array}{l}\text { gi|354,545,590 } \\
\text { (CCE42318) }\end{array}$ & $\begin{array}{l}\text { hypothetical protein CPAR2_808670 } \\
\text { [Candida parapsilosis] } \\
\text { glyceraldehyde-3-phosphate } \\
\text { dehydrogenase (Tdh3) }\end{array}$ & 0.07167 & - & - & $0.11546^{\mathrm{ns}}$ & $0.07485^{\mathrm{ns}}$ \\
\hline $\begin{array}{l}\text { gi|354,545,888 } \\
\text { (CCE42617) }\end{array}$ & $\begin{array}{l}\text { hypothetical protein CPAR2_202600 } \\
\text { [Candida parapsilosis] } \\
\text { transaldolase (Tal1) }\end{array}$ & 0.06634 & - & - & $0.08495^{\mathrm{ns}}$ & $0.02001^{* *}$ \\
\hline $\begin{array}{l}\text { gi|354,547,143 } \\
\text { (CCE43876) }\end{array}$ & $\begin{array}{l}\text { hypothetical protein CPAR2_501020 } \\
\text { [Candida parapsilosis] } \\
\text { pyruvate decarboxylase (Pdc11) }\end{array}$ & 0.01985 & - & - & $0.03279^{* * *}$ & $0.02973^{\mathrm{ns}}$ \\
\hline $\begin{array}{l}\text { gi|354,543,158 } \\
\text { (CCE39876) }\end{array}$ & $\begin{array}{l}\text { hypothetical protein CPAR2_602950 } \\
\text { [Candida parapsilosis] } \\
\text { phosphoglycerate kinase (Pgk1) }\end{array}$ & - & - & - & $0.12601^{\uparrow}$ & $0.08621^{\uparrow}$ \\
\hline $\begin{array}{l}\text { gi|354,543,177 } \\
\text { (CCE39895) }\end{array}$ & $\begin{array}{l}\text { hypothetical protein CPAR2_603140 } \\
\text { [Candida parapsilosis] } \\
\text { putative ketol-acid reductoisomerase (IIv5) }\end{array}$ & - & - & - & - & $0.01782^{\uparrow}$ \\
\hline $\begin{array}{l}\text { gi|354,543,405 } \\
\text { (CCE40124) }\end{array}$ & $\begin{array}{l}\text { hypothetical protein CPAR2_101620 } \\
\text { [Candida parapsilosis] } \\
\text { acetyl-coA hydrolase (Ach1) }\end{array}$ & - & - & - & - & $0.01021^{\uparrow}$ \\
\hline $\begin{array}{l}\text { gi|354,545,521 } \\
\text { (CCE42249) }\end{array}$ & $\begin{array}{l}\text { hypothetical protein CPAR2_807980 } \\
\text { [Candida parapsilosis] } \\
\text { triosephosphate isomerase (Tpi) }\end{array}$ & - & - & - & - & $0.04040^{\uparrow}$ \\
\hline $\begin{array}{l}\text { gi|354,545,980 } \\
\text { (CCE42709) }\end{array}$ & $\begin{array}{l}\text { hypothetical protein CPAR2_203520 } \\
\text { [Candida parapsilosis] } \\
\text { 6-phosphogluconate dehydrogenase (Gnd1) }\end{array}$ & - & - & - & - & $0.01057^{\uparrow}$ \\
\hline $\begin{array}{l}\text { gi|354,546,116 } \\
\text { (CCE42845) }\end{array}$ & $\begin{array}{l}\text { hypothetical protein CPAR2_204880 } \\
\text { [Candida parapsilosis] } \\
\text { phosphoglucose isomerase (Pgi1) }\end{array}$ & - & - & - & - & $0.01127^{\uparrow}$ \\
\hline $\begin{array}{l}\text { gi|354,546,805 } \\
\text { (CCE43537) }\end{array}$ & $\begin{array}{l}\text { hypothetical protein CPAR2_211810 } \\
\text { [Candida parapsilosis] } \\
\text { phosphoglycerate mutase (Gpm1) }\end{array}$ & - & - & - & - & $0.07052^{\uparrow}$ \\
\hline $\begin{array}{l}\text { gi|354,546,845 } \\
\text { (CCE43577) }\end{array}$ & $\begin{array}{l}\text { hypothetical protein CPAR2_212210 } \\
\text { [Candida parapsilosis] } \\
\text { NAD-aldehyde dehydrogenase (Ald5) }\end{array}$ & - & $0.23428^{\uparrow}$ & - & - & \\
\hline $\begin{array}{l}\text { gi|354,547,299 } \\
\text { (CCE44033) }\end{array}$ & $\begin{array}{l}\text { hypothetical protein CPAR2_502580 } \\
\text { [Candida parapsilosis] } \\
\text { alcohol dehydrogenase (Adh1) }\end{array}$ & - & $0.13296^{\uparrow}$ & - & $0.08365^{\uparrow}$ & $0.13991^{\uparrow}$ \\
\hline $\begin{array}{l}\text { gi|354,547,586 } \\
\text { (CCE44321) }\end{array}$ & $\begin{array}{l}\text { hypothetical protein CPAR2_401230 } \\
\text { [Candida parapsilosis] } \\
\text { fructose-bisphosphate aldolase (Fba1) }\end{array}$ & - & - & - & - & $0.04268^{\uparrow}$ \\
\hline
\end{tabular}

Cell surface shaving of $C$. parapsilosis cultures with trypsin and additional digestion of the obtained proteins for $24 \mathrm{~h}$ was performed. The resulting peptides were then analyzed using the Dionex Ultimate 3000 UHPLC system coupled to an HCTUltra ETDII mass spectrometer. The obtained lists of peaks were searched against the NCBI protein database using an in-house Mascot server. The normalized abundance factors (NSAFs) were calculated for each of the tested growth conditions and the statistical significance with respect to the defined synthetic medium is indicated as follows: ** $p$ from 0.001 to 0.01 , *** $p$ from 0.0001 to 0.001 ; and ns, not significant by Student $t$-test. The arrows indicate that the protein was only identified from cultures grown in AS, VS, AU or AN and not in the synthetic medium

plasticity of the fungal cell wall in C. albicans cultures and also considerable changes to the composition of the typical cell wall proteins [46].

Using the same method as in this work, i.e., the cell surface shaving with trypsin, proteins present at the surface of various morphological forms of $C$. albicans cells were also characterized [23, 24]. On inspection of this very large group of proteins, a particularly interesting is a large abundance of moonlighting proteins, including Tdh3, Eno1, Pgk1, Adh1, Tal1 and Pdc11 [24]. The presence of such the proteins at the surface of $C$. albicans cells has been explained by their non-classical way of secretion inside the extracellular vesicles [47, 48]. This phenomenon may explain the surface location of not 
Table 3 Mass spectrometry identification of C. tropicalis moonlighting proteins present at the cell surface after growth under different conditions

\begin{tabular}{|c|c|c|c|c|c|c|}
\hline $\begin{array}{l}\text { NCBI accession } \\
\text { number }\end{array}$ & Protein description & $\begin{array}{l}\text { defined synthetic } \\
\text { medium (DS) }\end{array}$ & $\begin{array}{l}\text { artificial } \\
\text { saliva (AS) }\end{array}$ & $\begin{array}{l}\text { vagina- simulative } \\
\text { medium (VS) }\end{array}$ & $\begin{array}{l}\text { artificial } \\
\text { urine (AU) }\end{array}$ & $\begin{array}{l}\text { anaerobic } \\
\text { conditions (AN) }\end{array}$ \\
\hline $\begin{array}{l}\text { gi|255,727,881 } \\
\left(X P \_002548866\right)\end{array}$ & $\begin{array}{l}\text { enolase } 1 \text { (Eno1) CTRG_03163 } \\
\text { [Candida tropicalis MYA-3404] }\end{array}$ & 0.08812 & $0.27053^{* *}$ & - & $0.32363^{* *}$ & $0.15934^{\mathrm{ns}}$ \\
\hline $\begin{array}{l}\text { gi|255,729,208 } \\
\left(X_{2} \text { 002549529) }\right.\end{array}$ & $\begin{array}{l}\text { pyruvate decarboxylase (Pdc11) } \\
\text { CTRG_03826 [Candida tropicalis } \\
\text { MYA-3404] }\end{array}$ & 0.04341 & - & - & - & $0.03722^{\mathrm{ns}}$ \\
\hline $\begin{array}{l}\text { gi|255,732,890 } \\
\text { (XP_002551368) }\end{array}$ & $\begin{array}{l}\text { glyceraldehyde-3-phosphate } \\
\text { dehydrogenase (Tdh3) CTRG_05666 } \\
\text { [Candida tropicalisMYA-3404] }\end{array}$ & 0.09736 & - & $0.57733^{* * * *}$ & - & $0.09534^{\mathrm{ns}}$ \\
\hline
\end{tabular}

Cell surface shaving of $C$. tropicalis cultures with trypsin and additional digestion of the obtained proteins for $24 \mathrm{~h}$ was performed. The resulting peptides were then analyzed using the Dionex Ultimate 3000 UHPLC system coupled to an HCTUltra ETDII mass spectrometer. The obtained lists of peaks were searched against the NCBI protein database using an in-house Mascot server. The normalized abundance factors (NSAFs) were calculated for each of the tested growth conditions and the statistical significance with respect to the defined synthetic medium is indicated as follows:** $p$ from 0.001 to 0.01 ; ${ }^{* * * *} p<0.0001$; and ns, not significant by Student $t$-test

only the above named proteins but also other atypical cell wall proteins of primarily cytoplasmic origin, such as phosphoglycerate mutase (Gpm1) [47], triosephosphate isomerase (Tpi1) and 6-phosphogluconate dehydrogenase (Gnd1) [48].

No detailed data have been reported on changes of cell wall proteome thus far in any species other than C. albicans. However, given the changes observed in the epidemiology of infections caused by Candida species and, in particular the increase in the incidence of serious candidiases caused by non-albicans Candida species such as C. glabrata, C. parapsilosis and C. tropicalis [49], there is an urgent need to analyze the cell wall proteomes of these fungi to devise possible new treatments for these severe infections.

Within the class of typical fungal cell wall proteins that are often involved in wall maintenance, or that can act as fungal virulence factors involved in the adhesion to host cells or hydrolysis of host macromolecular targets, the proteins identified in non-albicans Candida species in our present study are potentially very important factors in the infectious diseases caused by these microbes. In C. glabrata, the aspartic protease Yps3, shown previously to be required for virulence [50], was detected in cultures grown in DS and AS, the cell wall mannoprotein Cwp1 in AS cultures only, and the glucosidase Scw4/Mp65 in both of these media and in VS. The two latter proteins belong to the core set of proteins consistently present in the cell wall of C. glabrata [51] that, together with other typical cell wall proteins with enzymatic activity and adhesins from Epa and Awp family, function in the maintenance and remodeling of the fungal cell wall and adhesion of C. glabrata cells [52]. In $C$. parapsilosis and $C$. tropicalis, the cell wall mannoprotein Mp65, the ortholog of which is involved in adhesion and biofilm formation in C. albicans [53], was detected after growth in VS and additionally in AS for C. parapsilosis and $\mathrm{AN}$ for $C$. tropicalis. In addition to these classical cell wall proteins, a significant increase in the surface exposure of moonlighting proteins in different growth media was observed. Some of these proteins were detected at the surface of cultured cells in all of the media tested, such as Eno1 and Tdh3 in C. glabrata. These two proteins were detected at the cell surface of all investigated species together with Pdc11. C. glabrata Pdc11 was detected in VS, AU and AN cultures, C. parapsilosis Eno1, Tdh3 and Pdc11 in DS, AU and AN, C. tropicalis Eno1 in DS and AN, and a significant increase in the NSAFs for this protein was observed in AS- and AUgrown cells. C. tropicalis Pdc11 and Tdh3 were identified in DS and AN media, whereas an increased level of the latter protein was detected in VS. Moreover, in our previous studies, Pdc11, Eno1 andTdh3 were also identified at the surface of $C$. parapsilosis and C. tropicalis cells grown under aerobic conditions in YPD medium, and the latter also in the YPD buffered medium with lowered content of animal-derived peptone (YAPD) [26]. Such the observation strongly emphasizes the widespread presence and abundance of Pdc11, Eno1 and Tdh3 on the cell wall of the investigated species. As demonstrated in other studies, these three proteins located at the cell surfaces of selected non-albicans Candida species, additionally including fructosebisphosphate aldolase (Fba1), Gpm1 and Pgk1 identified also at the cell surface of C. glabrata and C. parapsilosis in our present analysis, are variously regulated during the response to oxidative stress $[17,18]$. Recently, the activity of a transglutaminase was assigned to surfaceexposed C. albicans Eno1, confirming the important role of this protein in the maintenance of cell wall integrity, in fungal morphological transition and in the protection against osmotic stress [54]. Among the moonlighting proteins identified at the surface of $C$. parapsilosis and C. tropicalis in this work, there are also proteins that have been proven to possess strong immunogenic properties. In $C$. parapsilosis, these are proteins such as 
Eno1, Tdh3, Pdc11, Adh1 and Fba1 [55] and in the case of C. tropicalis also Eno1 and Tdh3 [56].

Yeast enolase is a well-known protein that binds human plasminogen [57]. It has been suggested that interactions of $C$. albicans enolase and plasminogen might facilitate the invasion of endothelial cells [58]. This protein was also shown to bind three proteinaceous components of the human plasma contact system-kininogen, coagulation factor XII and plasma prekallikrein-possibly leading to the activation of this system and the generation of the vasoactive and proinflammatory peptides, the kinins [11, 14]. In addition, $C$. tropicalis enolase was identified as a kininogen-binding protein [13]. Some of the proteins identified in our current experiments were suggested previously to be responsible for adhesion to the human extracellular matrix proteins-fibronectin, vitronectin or laminin. This includes C. parapsilosis Eno1, Gnd1, phosphoglucose isomerase (Pgi1) and Gpm1 and C. tropicalis Eno1 [8]. An ortholog of Tdh3 from the C. albicans cell wall was also demonstrated previously to possess fibronectin and laminin binding activity [7].

\section{Conclusions}

The abundant presence of moonlighting proteins at the surfaces of fungal cells under various growth conditions, the observed increases in the levels of these factors under conditions that mimic infectious niches, and the substantial evidence in prior reports for the involvement of many of these particular proteins in pathogen-host interactions, suggest the importance of the functions performed at the cell surface by these molecules in facilitating the adherence of fungal cells to host tissues and the further dissemination of infection. Moreover, the universal occurrence of atypical cell wall proteins with a diversity of physicochemical properties in important fungal pathogens [1] warrants continuing further research on the involvement of these factors in the virulence of these microbes due to their wide impact on human health.

\section{Methods}

\section{Candida strains analyzed in this study and their growth} conditions

C. glabrata (Anderson) Meyer et Yarrow strain CBS138 $\left(\right.$ ATCC $^{\circ} 2001^{\mathrm{mt}}$ ), C. parapsilosis (Ashford) Langeron et Talice strain CDC 317 (ATCC ${ }^{\bullet}$ MYA-4646 ${ }^{\mathrm{ma}}$ ) and C. tropicalis (Castellani) Berkhout strain T1 (ATCC ${ }^{\circ}$ MYA$3404^{\mathrm{m}}$ ) were purchased from American Type Culture Collection (Manassas, VA). Cells were cultured in YPD medium (1\% yeast extract, $2 \%$ soybean peptone and $2 \%$ glucose, pH 6.0; Sigma, St. Louis, MO) for $16 \mathrm{~h}$ at $30^{\circ} \mathrm{C}$, and $5 \times 10^{8}$ cell aliquots were inoculated into $20 \mathrm{ml}$ of various growth media and further cultured aerobically for $16 \mathrm{~h}$ or anaerobically for $72 \mathrm{~h}$ at $37^{\circ} \mathrm{C}$ on an orbital rotary shaker MaxQ 6000 (170 rpm) (Thermo Fisher Scientific, Waltham, MA). Anoxic conditions were created using a GENbox jar with a GENboxanaer generator (bioMérieux SA, Marcy l'Etoile, France). Cell numbers were determined by optical density measurements at $600 \mathrm{~nm}$.

The compositions of the different growth media used for fungal cultures are as follows: (i) DS - an amino acid-based, chemically defined synthetic medium composed of $5 \mathrm{~g} / \mathrm{l}\left(\mathrm{NH}_{4}\right)_{2} \mathrm{SO}_{4}, 0.2 \mathrm{~g} / \mathrm{l} \mathrm{MgSO}_{4} \cdot 7 \mathrm{H}_{2} \mathrm{O}, 2.5 \mathrm{~g} / \mathrm{l}$ $\mathrm{K}_{2} \mathrm{HPO}_{4}, 5 \mathrm{~g} / \mathrm{l} \mathrm{NaCl}$ (Avantor Performance Materials Poland S.A., Gliwice, Poland), $0.5 \mathrm{~g} / \mathrm{l}$ alanine, $1.3 \mathrm{~g} / \mathrm{l}$ leucine, $1 \mathrm{~g} / \mathrm{l}$ lysine, $0.1 \mathrm{~g} / \mathrm{l}$ methionine, $0.5 \mathrm{~g} / \mathrm{l}$ phenyloalanine, $0.5 \mathrm{~g} / 1$ proline, $0.5 \mathrm{~g} / \mathrm{l}$ threonine (BioShop Canada Inc., Burlington, Ontario, Canada), $0.0714 \mathrm{~g} / \mathrm{l}$ ornithine (Sigma), $0.001 \mathrm{~g} / \mathrm{l}$ biotin (SERVA Electrophoresis $\mathrm{GmbH}$, Heidelberg, Germany) and 1.25\% glucose, pH 6.8, and prepared in strict accordance with the original procedure developed by Lee et al. [35]; (ii) AS - artificial saliva comprising $2.5 \mathrm{~g} / \mathrm{l}$ mucin from a porcine stomach, type III, $10.0 \mathrm{~g} / \mathrm{l}$ animal peptone, $5.0 \mathrm{~g} / \mathrm{l}$ trypticase peptone, $5.0 \mathrm{~g} / \mathrm{l}$ yeast extract, $5 \mathrm{mg} / \mathrm{l}$ hemin, $1 \mathrm{mg} / \mathrm{l}$ menadione, $60 \mathrm{mg} / \mathrm{l}$ urea (Sigma), $174 \mathrm{mg} / \mathrm{l}$ arginine (BioShop) and $2.5 \mathrm{~g} / \mathrm{l} \mathrm{KCl}, \mathrm{pH} 7.0$ [29]; (iii) VS - vagina-simulative medium composed of $18 \mathrm{mg} / \mathrm{l}$ of bovine serum albumin (BioShop), $3.5 \mathrm{~g} / \mathrm{l} \mathrm{NaCl}, 1.4 \mathrm{~g} / \mathrm{l} \mathrm{KOH}, 0.22 \mathrm{~g} / \mathrm{l} \mathrm{Ca}(\mathrm{OH})_{2}$ (Avantor Performance Materials Poland S.A.), $2.2 \mathrm{~g} / \mathrm{l}$ of $90 \%$ lactic acid, $0.32 \mathrm{~g} / \mathrm{l}$ of $50 \%$ glycerol, $0.4 \mathrm{~g} / \mathrm{l}$ urea (Sigma), $1 \mathrm{~g} / \mathrm{l}$ of glacial acetic acid (Merck, Darmstadt, Germany) and 0.5\% glucose, pH 4.2 [30]; (iv) AU - artificial urine composed of $0.65 \mathrm{~g} / \mathrm{l} \mathrm{CaCl}, 0.65 \mathrm{~g} / 1 \mathrm{MgCl}_{2}$, $4.6 \mathrm{~g} / \mathrm{l} \mathrm{NaCl}, 2.3 \mathrm{~g} / \mathrm{l} \mathrm{Na} \mathrm{SO}_{4}, 0.65 \mathrm{~g} / 1 \mathrm{Na}_{3} \mathrm{C}_{3} \mathrm{H}_{5} \mathrm{O}\left(\mathrm{CO}_{2}\right)_{3}$, $0.02 \mathrm{~g} / \mathrm{l} \mathrm{Na} \mathrm{Na}_{2} \mathrm{C}_{2} \mathrm{O}_{4}, 2.8 \mathrm{~g} / \mathrm{l} \quad \mathrm{KH}_{2} \mathrm{PO}_{4}, 1.6 \mathrm{~g} / \mathrm{l} \mathrm{KCl}, 1.0 \mathrm{~g} / \mathrm{l}$ $\mathrm{NH}_{4} \mathrm{Cl}$ (Avantor Performance Materials Poland S.A.), 25 $\mathrm{g} / \mathrm{l}$ urea, $1.1 \mathrm{~g} / \mathrm{l}$ of creatinine (Sigma) and $0.3 \%$ glucose, pH 5.8 [31]; and (v) AN - anaerobic growth conditions in YPD medium, $\mathrm{pH}$ 6.0.

\section{Cell surface shaving with trypsin}

The release and isolation of peptides from surfaceexposed fungal proteins for further identification using shotgun proteomics was performed by cell surface shaving with trypsin as described previously [26] with minor modifications. Briefly, C. glabrata, C. parapsilosis and C. tropicalis cells $\left(5 \times 10^{8}\right)$ cultured under different conditions were harvested by centrifugation ( $3 \mathrm{~min}, 3000 \mathrm{rpm})$ and washed twice with $1 \mathrm{ml}$ of phosphate buffered saline (PBS), pH 7.4 and then twice with $1 \mathrm{ml}$ of $25 \mathrm{mM}$ ammonium bicarbonate buffer $\left(\mathrm{NH}_{4} \mathrm{HCO}_{3}\right)$. The cells were then mixed with $1 \mu \mathrm{g}$ of sequencing-grade trypsin (Promega, Madison, WI) in $100 \mu \mathrm{l}$ of $25 \mathrm{mM} \mathrm{NH} \mathrm{NHCO}_{3}$ and $5 \mathrm{mM}$ dithiothreitol (DTT) (Bioshop). After an incubation for $10 \mathrm{~min}$ at $37^{\circ} \mathrm{C}$, cell suspensions were centrifuged $(5 \mathrm{~min}$, $3000 \mathrm{rpm}$ ), and the peptide-rich supernatants were passed through $0.22 \mu \mathrm{m}$ filters (Merck) and incubated for an 
additional $24 \mathrm{~h}$ at $37^{\circ} \mathrm{C}$ to enhance tryptic digestion. The reaction was subsequently stopped by the addition of trifluoroacetic acid (TFA) (Sigma) to a final concentration of $0.1 \%$ and further incubated for $15 \mathrm{~min}$ at $4{ }^{\circ} \mathrm{C}$. The protein precipitates were then discarded and the supernatants containing the peptides were centrifuged (12 min, 12,000 rpm) and dried in a Speed-Vac (Martin Christ, Osterode am Harz, Germany). Three independent biological replicates were prepared from the cells of each Candida species cultured under particular growth conditions.

\section{Protein identification by liquid chromatography-coupled tandem mass spectrometry}

The peptides obtained after tryptic digestion of the fungal cultures were identified using high performance liquid chromatography-coupled tandem mass spectrometry (LCMS/MS). Each peptide-containing sample was dissolved in $110 \mu \mathrm{l}$ of $10 \%$ acetonitrile (ACN) with $0.1 \%$ formic acid, centrifuged for $12 \mathrm{~min}$ at $12000 \mathrm{rpm}$ ) and transferred to new vials. Peptides were separated on a $100 \mathrm{~mm} \times 2.1 \mathrm{~mm}$ Aeris $3.6 \mu \mathrm{m}$ PEPTIDE XB-C18 column (Phenomenex, Torrance, CA), with a $10-55 \%$ gradient of $0.1 \%$ formic acid in $80 \% \mathrm{ACN}$ for $60 \mathrm{~min}$ via a flow rate of $0.1 \mathrm{ml} / \mathrm{min}$ using ultra-high-performance liquid chromatography Dionex Ultimate 3000 system. They were then analyzed using a HCTUltra ETDII ion-trap mass spectrometer equipped with an electrospray ionization ion source and HyStar 3.2 software (Bruker, Bremen, Germany). The mass spectrometer was operated in a standard MS/MS mode with simultaneous fragmentation of the most intensive precursor ions by collision-induced dissociation. The mass range was 200 to $1800 \mathrm{~m} / \mathrm{z}$ for MS scanning with an Enhanced Mode (speed $8100 \mathrm{~m} / \mathrm{z} / \mathrm{s}$ ), the target mass was at $800 \mathrm{~m} / \mathrm{z}$ and the maximum accumulation time was set to $100 \mathrm{~ms}$ to avoid overloading of the ion trap. The data dependent MS/MS scan events were acquired using a smart parameter setting (SPS) with the intensity threshold set at $1 \times 10^{4}$, and a maximum accumulation time of $50 \mathrm{~ms}$. Capillary voltages were set to $4 \mathrm{kV}$ and the capillary temperature was $350^{\circ} \mathrm{C}$.

Mascot Generic format (.mgf) files were generated by pre-processing the raw data with Data Analysis 4.0 software (Bruker). The lists of obtained peaks were searched against the non-redundant NCBI protein database with a taxonomy restriction for fungi $(26,490,256$ sequences for all entries; $1,924,810$ sequences for fungal proteins) using Biotools 3.2 software (Bruker) and an in-house Mascot server v.2.3.0 (Matrix Science, London, UK). The following search parameters were applied: enzyme specificity, trypsin; permitted number of missed cleavages, 2; fixed modification, carbamidomethylation $(\mathrm{C})$; variable modifications, oxidation $(M)$; charge state, $1+, 2+, 3+; C^{13}$ number, 1; mass values, monoisotopic; experimental peptide mass value tolerance (Mass Tol.) of $\pm 0.3 \mathrm{Da}$; and a fragment ion mass tolerance (MS/MS Tol.) of $\pm 0.3 \mathrm{Da}$. After peptide identification, a final dataset was prepared based on the normalized spectral abundance factors (NSAFs) [59] but taking into consideration only those proteins that were identified with a Mascot Score greater than $67(p<0.05)$. NSAFs were calculated by dividing the spectral number $(\mathrm{SpC})$ of each protein by its length ( $\mathrm{L}$, number of amino acids) and this value was then normalized by dividing by the sum of all $\mathrm{SpC} / \mathrm{L}$ for all proteins identified in the composite mixture and listed in the Additional file 2: Table S2, Additional file 3: Table S3 and Additional file 4: Table S4 together with the data necessary for the calculation (Additional files 2, 3 and 4).

The statistical significance of the relative change in NSAF values calculated for each cell wall protein identified for a particular growth medium with respect to the defined synthetic medium, was analyzed by the Student $t$-test using GraphPad Prism 6 software (La Jolla, CA).

\section{Additional files}

Additional file 1: Table S1. Mass spectrometry identification of C. glabrata, C. parapsilosis and C. tropicalis proteins present at the cell surface under different growth conditions. (PDF $232 \mathrm{~kb}$ )

Additional file 2: Table S2. Mass spectrometry identification of C. glabrata proteins present at the cell surface under different growth conditions. (PDF $279 \mathrm{~kb}$ )

Additional file 3: Table S3. Mass spectrometry identification of $C$. parapsilosis proteins present at the cell surface under different growth conditions. (PDF $261 \mathrm{~kb}$ )

Additional file 4: Table S4. Mass spectrometry identification of C. tropicalis proteins present at the cell surface under different growth conditions. (PDF $224 \mathrm{~kb}$ )

Additional file 5: Figure S1. Relative differences in the level of expression of selected surface-exposed moonlighting proteins depending on the type of medium used. (PDF $171 \mathrm{~kb}$ )

\section{Abbreviations}

AN: Anaerobic conditions; AS: Artificial saliva; AU: Artificial urine; DS: An amino acid defined synthetic medium; GO: Gene ontology; LC-MS/MS: High performance liquid chromatography-coupled tandem mass spectrometry; NSAFs: Normalized spectral abundance factors; Vs: Vagina-simulative medium

\section{Acknowledgements}

Not applicable.

\section{Authors' contributions}

JKK and AK conceived and designed the study and interpreted the data. JKK wrote the paper and AK edited the final manuscript version. JKK and DS participated in all of the experiments. DS performed the statistical analyses and OB was involved in the LC-MS/MS analyses. MRK assisted with the data interpretation and contributed to the writing and editing of the manuscript. All of the study authors read and approved the final manuscript and its submission for publication.

\section{Funding}

This work was supported in part by the National Science Centre of Poland (grant no. 2016/23/B/NZ6/00089 awarded to A.K.). The Faculty of Biochemistry, Biophysics and Biotechnology of the Jagiellonian University in Krakow is a beneficiary of structural funds from the European Union (grant no. POIG.02.01.00-12-064/08, "Molecular biotechnology for health") and a partner of the Leading National Research Center (KNOW) supported by the 
Ministry of Science and Higher Education, Poland. The funding bodies had no role in the study design, data collection or interpretation, writing of the manuscript, or the decision to submit the work for publication.

\section{Availability of data and materials}

All data generated or analyzed during this study are included in this published article and its supplementary information files.

\section{Ethics approval and consent to participate}

Not applicable.

\section{Consent for publication}

Not applicable.

\section{Competing interests}

The authors declare that they have no competing interests.

\section{Author details \\ ${ }^{1}$ Department of Comparative Biochemistry and Bioanalytics, Faculty of Biochemistry, Biophysics and Biotechnology, Jagiellonian University, Gronostajowa 7, 30-387, Krakow, Poland. 2Department of Analytical Biochemistry, Faculty of Biochemistry, Biophysics and Biotechnology, Jagiellonian University, Gronostajowa 7, 30-387, Kraków, Poland.}

Received: 4 October 2018 Accepted: 20 June 2019

Published online: 03 July 2019

\section{References}

1. Amblee $V$, Jeffery $C J$. Physical features of intracellular proteins that moonlight on the cell surface. PLoS One. 2015;10:e0130575. https:/doi.org/ 10.1371/journal.pone.0130575.

2. Jeffery CJ. Moonlighting proteins. Trends Biochem Sci. 1999;24:8-11.

3. Henderson B, Martin A. Bacterial virulence in the moonlight: multitasking bacterial moonlighting proteins are virulence determinants in infectious disease. Infect Immun. 2011;79:3476-91. https://doi.org/10.1128/IAI.00179-11.

4. Wang G, Xia Y, Cui J, Gu Z, Song Y, Chen YQ, et al. The roles of moonlighting proteins in bacteria. Curr Issues Mol Biol. 2014;16:15-22.

5. Horn DL, Neofytos D, Anaissie EJ, Fishman JA, Steinbach WJ, Olyaei AJ, et al. Epidemiology and outcomes of candidemia in 2019 patients: data from the prospective antifungal therapy alliance registry. Clin Infect Dis. 2009;48: 1695-703. https://doi.org/10.1086/599039.

6. Wisplinghoff H, Ebbers J, Geurtz L, Stefanik D, Major Y, Edmond MB, et al. Nosocomial bloodstream infections due to Candida spp. in the USA: species distribution, clinical features and antifungal susceptibilities. Int J Antimicrob Agents. 2014;43:78-81. https://doi.org/10.1016/j.jiantimicag.2013.09.005.

7. Gozalbo D, Gil-Navarro I, Azorín I, Renau-Piqueras J, Martínez JP, Gil ML. The cell wall-associated glyceraldehyde-3-phosphate dehydrogenase of Candida albicans is also a fibronectin and laminin binding protein. Infect Immun. 1998:66:2052-9.

8. Kozik A, Karkowska-Kuleta J, Zajac D, Bochenska O, Kedracka-Krok S, Jankowska U, Rapala-Kozik M. Fibronectin-, vitronectin- and laminin-binding proteins at the cell walls of Candida parapsilosis and Candida tropicalis pathogenic yeasts. BMC Microbiol. 2015;15:197. https://doi.org/10.1186/ s12866-015-0531-4.

9. Crowe JD, Sievwright IK, Auld GC, Moore NR, Gow NA, Booth NA. Candida albicans binds human plasminogen: identification of eight plasminogenbinding proteins. Mol Microbiol. 2003;47:1637-51.

10. Poltermann S, Kunert A, von der Heide M, Eck R, Hartmann A, Zipfel PF. Gpm1 $\mathrm{p}$ is a factor $\mathrm{H}$-, $\mathrm{FHL}-1$-, and plasminogen-binding surface protein of Candida albicans. J Biol Chem. 2007:282:37537-44.

11. Karkowska-Kuleta J, Kedracka-Krok S, Rapala-Kozik M, Kamysz W, Bielinska S, Karafova A, Kozik A. Molecular determinants of the interaction between human high molecular weight kininogen and Candida albicans cell wall: identification of kininogen-binding proteins on fungal cell wall and mapping the cell wall-binding regions on kininogen molecule. Peptides. 2011;32:2488-96. https://doi.org/10.1016/j.peptides.2011.10.021.

12. Karkowska-Kuleta J, Zajac D, Bras G, Bochenska O, Rapala-Kozik M, Kozik A. Binding of human plasminogen and high-molecular-mass kininogen by cell surface-exposed proteins of Candida parapsilosis. Acta Biochim Pol. 2017;64: 391-400. https://doi.org/10.18388/abp.2017_1609.
13. Karkowska-Kuleta J, Zajac D, Bras G, Bochenska O, Seweryn K, Kedracka-Krok $\mathrm{S}$, et al. Characterization of the interactions between human highmolecular-mass kininogen and cell wall proteins of pathogenic yeasts Candida tropicalis. Acta Biochim Pol. 2016;63:427-36. https://doi.org/10. 18388/abp.2016_1353.

14. Seweryn K, Karkowska-Kuleta J, Wolak N, Bochenska O, Kedracka-Krok S, Kozik A, Rapala-Kozik M. Kinetic and thermodynamic characterization of the interactions between the components of human plasma kinin-forming system and isolated and purified cell wall proteins of Candida albicans. Acta Biochim Pol. 2015;62:825-35. https://doi.org/10.18388/abp.2015_1142.

15. Lopez CM, Wallich R, Riesbeck K, Skerka C, Zipfel PF. Candida albicans uses the surface protein Gpm1 to attach to human endothelial cells and to keratinocytes via the adhesive protein vitronectin. PLoS One. 2014:9:e90796. https://doi.org/10.1371/journal.pone.0090796.

16. Núñez-Beltrán A, López-Romero E, Cuéllar-Cruz M. Identification of proteins involved in the adhesion of Candida species to different medical devices. Microb Pathog. 2017;107:293-303. https://doi.org/10.1016/j.micpath.2017.04.009.

17. Ramírez-Quijas MD, López-Romero E, Cuéllar-Cruz M. Proteomic analysis of cell wall in four pathogenic species of Candida exposed to oxidative stress. Microb Pathog. 2015;87:1-12. https://doi.org/10.1016/j.micpath.2015.07.011.

18. Serrano-Fujarte I, López-Romero E, Cuéllar-Cruz M. Moonlight-like proteins of the cell wall protect sessile cells of Candida from oxidative stress. Microb Pathog. 2016;90:22-33. https://doi.org/10.1016/j.micpath.2015.10.001.

19. Hall RA. Dressed to impress: impact of environmental adaptation on the Candida albicans cell wall. Mol Microbiol. 2015;97:7-17. https://doi.org/10. 1111/mmi.13020.

20. Pfaller M, Neofytos D, Diekema D, Azie N, Meier-Kriesche HU, Quan SP, Horn D. Epidemiology and outcomes of candidemia in 3648 patients: data from the prospective antifungal therapy (PATH Alliance ${ }^{\oplus}$ ) registry, 2004-2008. Diagn Microbiol Infect Dis. 2012;74:323-31. https://doi.org/10.1016/j. diagmicrobio.2012.10.003.

21. Bitew A, Abebaw Y. Vulvovaginal candidiasis: species distribution of Candida and their antifungal susceptibility pattern. BMC Womens Health. 2018;18:94. https://doi.org/10.1186/s12905-018-0607-z.

22. Sadeghi G, Ebrahimi-Rad M, Mousavi SF, Shams-Ghahfarokhi M, RazzaghiAbyaneh M. Emergence of non-Candida albicans species: epidemiology, phylogeny and fluconazole susceptibility profile. J Mycol Med. 2018;28:51-8. https://doi.org/10.1016/j.mycmed.2017.12.008

23. Vialás $V$, Perumal $P$, Gutierrez D, Ximénez-Embún P, Nombela C, Gil C, Chaffin WL. Cell surface shaving of Candida albicans biofilms, hyphae, and yeast form cells. Proteomics. 2012;12(14):2331-9. https://doi.org/10.1002/ pmic.201100588.

24. Gil-Bona A, Parra-Giraldo CM, Hernáez ML, Reales-Calderon JA, Solis NV, Filler SG, et al. Candida albicans cell shaving uncovers new proteins involved in cell wall integrity, yeast to hypha transition, stress response and hostpathogen interaction. J Proteome. 2015;127:340-51. https://doi.org/10.1016/ j.jprot.2015.06.006.

25. Gil-Bona A, Amador-García A, Gil C, Monteoliva L. The external face of Candida albicans: a proteomic view of the cell surface and the extracellular environment. J Proteome. 2018;180:70-9. https://doi.org/10. 1016/j.jprot.2017.12.002.

26. Karkowska-Kuleta J, Zajac D, Bochenska O, Kozik A. Surfaceome of pathogenic yeasts, Candida parapsilosis and Candida tropicalis, revealed with the use of cell surface shaving method and shotgun proteomic approach. Acta Biochim Pol. 2015;62:807-19. https://doi.org/10.18388/abp.2015_1140.

27. Arnaud MB, Costanzo MC, Skrzypek MS, Binkley G, Lane C, Miyasato SR, Sherlock G. The Candida genome database (CGD), a community resource for Candida albicans gene and protein information. Nucleic Acids Res. 2005; 33(Database issue):D358-63.

28. Cherry JM, Hong EL, Amundsen C, Balakrishnan R, Binkley G, Chan ET, et al. Saccharomyces genome database: the genomics resource of budding yeast. Nucleic Acids Res. 2012;40(Database issue):D700-5. https://doi.org/10.1093/ nar/gkr1029

29. Wong L. Sissons C. a comparison of human dental plaque microcosm biofilms grown in an undefined medium and a chemically defined artificial saliva. Arch Oral Biol. 2001:46:477-86.

30. Moosa MY, Sobel JD, Elhalis H, Du W, Akins RA. Fungicidal activity of fluconazole against Candida albicans in a synthetic vagina-simulative medium. Antimicrob Agents Chemother. 2004;48:161-7.

31. Silva S, Negri M, Henriques M, Oliveira R, Williams D, Azeredo J. Silicone colonization by non-Candida albicans Candida species in the presence of 
urine. J Med Microbiol. 2010;59:747-54. https://doi.org/10.1099/jmm.0. 017517-0.

32. Albenberg L, Esipova TV, Judge CP, Bittinger $K$, Chen J, Laughlin A, et al. Correlation between intraluminal oxygen gradient and radial partitioning of intestinal microbiota. Gastroenterology. 2014;147:1055-63.e8. https://doi.org/ 10.1053/j.gastro.2014.07.020.

33. Zheng L, Kelly CJ, Colgan SP. Physiologic hypoxia and oxygen homeostasis in the healthy intestine. A review in the theme: cellular responses to hypoxia. Am J Physiol Cell Physiol. 2015;309:C350-60. https://doi.org/10. 1152/ajpcell.00191.2015.

34. Gorkiewicz G, Moschen A. Gut microbiome: a new player in gastrointestinal disease. Virchows Arch. 2018;472:159-72. https://doi.org/10.1007/s00428017-2277-x.

35. Lee KL, Buckley HR, Campbell CC. An amino acid liquid synthetic medium for the development of mycelial and yeast forms of Candida albicans. Sabouraudia. 1975;13:148-53.

36. Ruiz-Herrera J, Elorza MV, Valentín E, Sentandreu R. Molecular organization of the cell wall of Candida albicans and its relation to pathogenicity. FEMS Yeast Res. 2006;6:14-29.

37. Takahashi S, Kudoh A, Okawa Y, Shibata N. Significant differences in the cellwall mannans from three Candida glabrata strains correlate with antifungal drug sensitivity. FEBS J. 2012;279:1844-56. https://doi.org/10.1111/j.17424658.2012.08564.x.

38. Staniszewska M, Bondaryk M, Rabczenko D, Smoleńska-Sym G, Kurzatkowski W. Cell wall carbohydrates content of pathogenic Candida albicans strain morphological forms. Med Dosw Mikrobiol. 2013;65:119-28.

39. Chaffin WL. Candida albicans cell wall proteins. Microbiol Mol Biol Rev. 2008; 72:495-544. https://doi.org/10.1128/MMBR.00032-07.

40. Karkowska-Kuleta J, Kozik A. Cell wall proteome of pathogenic fungi. Acta Biochim Pol. 2015;62:339-51. https://doi.org/10.18388/abp.2015_1032.

41. Karkowska-Kuleta J, Kozik A. Moonlighting proteins as virulence factors of pathogenic fungi, parasitic protozoa and multicellular parasites. Mol Oral Microbiol. 2014;29:270-83. https://doi.org/10.1111/omi.12078.

42. Franco-Serrano L, Cedano J, Perez-Pons JA, Mozo-Villarias A, Piñol J, Amela I, Querol E. A hypothesis explaining why so many pathogen virulence proteins are moonlighting proteins. Pathog Dis. 2018. https://doi.org/10. 1093/femspd/fty046.

43. Sosinska GJ, de Groot PWJ, Teixeira de Mattos MJ, Dekker HL, de Koster CG, Hellingwerf KJ, Klis FM. Hypoxic conditions and iron restriction affect the cell-wall proteome of Candida albicans grown under vagina-simulative conditions. Microbiology. 2008;154:510-20. https://doi.org/10.1099/mic.0. 2007/012617-0.

44. Sorgo AG, Brul S, de Koster CG, de Koning L, Klis FM. Iron restrictioninduced adaptations in the wall proteome of Candida albicans. Microbiology. 2013;159:1673-82. https://doi.org/10.1099/mic.0.065599-0.

45. Sosinska GJ, de Koning LJ, de Groot PW, Manders EM, Dekker HL, Hellingwerf KJ, de Koster CG, Klis FM. Mass spectrometric quantification of the adaptations in the wall proteome of Candida albicans in response to ambient $\mathrm{pH}$. Microbiology. 2011;157:136-46. https:/doi.org/10.1099/mic.0.044206-0.

46. Ene IV, Heilmann CJ, Sorgo AG, Walker LA, de Koster CG, Munro CA, Klis FM, Brown AJ. Carbon source-induced reprogramming of the cell wall proteome and secretome modulates the adherence and drug resistance of the fungal pathogen Candida albicans. Proteomics. 2012;12:3164-79. https:// doi.org/10.1002/pmic.201200228.

47. Gil-Bona A, Llama-Palacios A, Parra CM, Vivanco F, Nombela C, Monteoliva L, Gil C. Proteomics unravels extracellular vesicles as carriers of classical cytoplasmic proteins in Candida albicans. J Proteome Res. 2015;14(1):142-53. https://doi.org/10.1021/pr5007944.

48. Vargas G, Rocha JD, Oliveira DL, Albuquerque PC, Frases S, Santos SS, et al. Compositional and immunobiological analyses of extracellular vesicles released by Candida albicans. Cell Microbiol. 2015;17(3):389-407. https://doi. org/10.1111/cmi.12374

49. Diekema D, Arbefeville S, Boyken L, Kroeger J, Pfaller M. The changing epidemiology of healthcare-associated candidemia over three decades. Diagn Microbiol Infect Dis. 2012;73:45-8. https://doi.org/10.1016/j. diagmicrobio.2012.02.001.

50. Kaur R, Ma B, Cormack BP. A family of glycosylphosphatidylinositol-linked aspartyl proteases is required for virulence of Candida glabrata. Proc Natl AcadSci U S A. 2007;104:7628-33.

51. Gómez-Molero E, de Boer AD, Dekker HL, Moreno-Martínez A, Kraneveld EA, Ichsan, et al. Proteomic analysis of hyperadhesive Candida glabrata clinical isolates reveals a core wall proteome and differential incorporation of adhesins. FEMS Yeast Res. 2015;15(8). https://doi.org/10.1093/femsyr/fov098.

52. de Groot PW, Kraneveld EA, Yin QY, Dekker HL, Gross U, Crielaard W, et al. The cell wall of the human pathogen Candida glabrata: differential incorporation of novel adhesin-like wall proteins. Eukaryot Cell. 2008;7(11): 1951-64. https://doi.org/10.1128/EC.00284-08.

53. Sandini S, Stringaro A, Arancia S, Colone M, Mondello F, Murtas S, Girolamo A, Mastrangelo N, De Bernardis F. The MP65 gene is required for cell wall integrity, adherence to epithelial cells and biofilm formation in Candida albicans. BMC Microbiol. 2011;11:106. https://doi.org/10.1186/1471-2180-11-106.

54. Reyna-Beltrán E, Iranzo M, Calderón-González KG, Mondragón-Flores R, Labra-Barrios ML, Mormeneo S, Luna-Arias JP. The Candida albicans ENO1 gene encodes a transglutaminase involved in growth, cell division, morphogenesis, and osmotic protection. J Biol Chem. 2018;293:4304-23. https://doi.org/10.1074/jbc.M117.810440.

55. Lee PY, Gam LH, Yong VC, Rosli R, Ng KP, Chong PP. Identification of immunogenic proteins of Candida parapsilosis by serological proteome analysis. J Appl Microbiol. 2014;116(4):999-1009. https://doi.org/10.1111/jam.12408.

56. Lee PY, Gam LH, Yong VC, Rosli R, Ng KP, Chong PP. Immunoproteomic analysis of antibody response to cell wall-associated proteins of Candida tropicalis. J Appl Microbiol. 2014;117(3):854-65. https://doi.org/10.1111/jam.12562.

57. Funk J, Schaarschmidt B, Slesiona S, Hallström T, Horn U, Brock M. The glycolytic enzyme enolase represents a plasminogen-binding protein on the surface of a wide variety of medically important fungal species. Int J Med Microbiol. 2016;306:59-68. https://doi.org/10.1016/j.jimm.2015.11.005.

58. Jong AY, Chen SH, Stins MF, Kim KS, Tuan TL, Huang SH. Binding of Candida albicans enolase to plasmin(ogen) results in enhanced invasion of human brain microvascular endothelial cells. J Med Microbiol. 2003;52:615-22.

59. Zybailov B, Mosley AL, Sardiu ME, Coleman MK, Florens L, Washburn MP. Statistical analysis of membrane proteome expression changes in Saccharomyces cerevisiae. J Proteome Res. 2006;5:2339-47.

\section{Publisher's Note}

Springer Nature remains neutral with regard to jurisdictional claims in published maps and institutional affiliations.

Ready to submit your research? Choose BMC and benefit from:

- fast, convenient online submission

- thorough peer review by experienced researchers in your field

- rapid publication on acceptance

- support for research data, including large and complex data types

- gold Open Access which fosters wider collaboration and increased citations

- maximum visibility for your research: over $100 \mathrm{M}$ website views per year

At $\mathrm{BMC}$, research is always in progress.

Learn more biomedcentral.com/submissions 